\title{
ANALISIS LIKUIDITAS DAN FINANCIAL LAVERAGE TERHADAP BETA PADA PERUSAHAAN YANG TERDAFTAR DI BURSA EFEK INDONESIA SETELAH AKUISISI
}

\author{
Rizka Hadya \\ Program Studi Manajemen, Universitas Ekasakti \\ rizkahadya@gmail.com
}

\begin{abstract}
The development of globalization, encouraging companies to continue to exist and thrive. One of the business of the company is to acquisition. the aims of this study are to examine the effect of Liquidity and Financial Leverage toward Beta correction in companies listed on the Stock Exchange after an acquisition during the years 2013-2017. The study was conducted with a purposive sampling, and acquired six companies with 15 announcement date of acquisition during Beta 2013-2017. Culculate is done before correction and correction method with the method of Fowler and Rorke 1 lead and 1 lag. And the results of this study found that, Liquidity and Financial Leverage not have a significant effect on beta stocks before and after an acquisition.
\end{abstract}

Keywords: Beta Correction, Liquidity, Financial Leverage

\begin{abstract}
ABSTRAK
Perkembangan era globalisasi, mendorong perusahaan untuk tetap eksis dan berkembang. Salah usaha yang dilakukan perusahaan adalah dengan Akuisisi.Penelitian ini bertujuan untuk melihat pengaruh Likuiditas dan Financial Lavarage terhadap Beta koreksi pada perusahaan yang terdaftar di BEI setelah mengalami Akuisisi selama tahun 2013-2017. Penelitian dilakukan dengan Purposive Sampling, dan didapat 6 perusahaan dengan 15 tanggal pengumuman Akuisisi selama tahun 2013-2017.Perhitungan Beta dilakukan dengan metode Fowler dan Rolke 1 lead dan 1 lag. Dan hasil penelitian ini didapatkan bahwa, Likuiditasdan Financial Laverage tidak memiliki pengaruh yang signifikan terhadap Beta saham setelah mengalami Akuisisi.
\end{abstract}

Kata Kunci ; Beta Koreksi, Likuiditas dan Finansial Laverage 


\section{PENDAHULUAN}

Adanya perubahan dalam dunia bisnis seperti era globalisasi, deregulasi IPTEK dan telekominikasi serta fregmentasi pasar, telah menciptakan persaingan yang semakin pesat diantara perusahaan - perusahaan untuk dapat mengembangkan strategi demi mempertahankan keberadaan atau bahkan menjadikan perusahaan berkembang lebih pesat. Salah satu cara yang dapat ditempuh perusahaan adalah melakukan take over diri menjadi satu perusahaan besar dan lebih kuat. Akusisi menjadi salah satu strategi yang dipilih oleh perusahaan. Akuisisi adalah pengambilan kepemilikan atau pengendalian atas saham atau asset suatu perusahaan oleh perusahaan lain, dan dalam peristiwa ini baik perusahaan pengambil alih atau diambil alih tetap eksis sebagai badan hukum yang terpisah.

Alasan utama perusahaan di Indonesia melakukan akuisisi pada dasarnya adalah untuk penghematan pajak. Pasar bereaksi positif terhadap pengumuman akuisisi yang bagi perusahaan target memiliki kandungan informasi sebagai berita baik. Dengan kata lain bahwa terdapat tambahan kemakmuran secara kumulatif yang terjadi selama periode sebelum pengumuman akuisisi maupun setelah tanggal pengumuman. Dengan demikian dapat dikatakan bahwa aktivitas akuisisi di Bursa Efek Indonesia (BEI) memberikan tambahan kemakmuran bagi pemegang saham perusahaan target.

Di era sekarang banyak sekali perusahaan yang telah melakukan akuisisi, baik perusahaan swasta ataupun perusahaan negara. Tujuannya sama yaitu untuk meningkatkan kinerja perusahaan dan mengembangkan perusahaan. Namun demikian akuisisi pada suatu perusahaan dapat menimbulkan beberapa dampak pada perusahaan yang diakuisisi. Terutama adanya perbedaan kinerja dan finasial dari perusahaan. Pengaruh akuisisi terhadap manajemen pengakuisisi dan manajemen target berbeda. Manajemen perusahaan pengakuisisi memiliki peluang dan tantangan yang lebih besar sekaligus harapan untuk mendapatkan pengakuan, kompensasi yang lebih tinggi. Dari perspektif manajer puncak, akuisisi menggiurkan dan sering menguntungkan secara finansial.

Laporan Keuangan bisa memberikan gambaran yang jelas untuk informasi mengenai struktur finansial yang telah berbeda mengakibatkan akan menimbulkan resiko dan return saham yang berbeda pula bagi pemegang saham. Kemungkinan resiko dan return saham akan terlihat berfluktuasi. Hal ini sangat mempengaruhi bagi pemegang saham. Untuk itu salah satu cara mengukur resiko dan return pada suatu saham atau portofolio adalah beta. Nilai Beta menggambarkan nilai risiko suatu saham. Beta suatu saham yang tinggi menunjukkan tingkat risiko yang tinggi pada saham tersebut, namun tingkat risiko yang tinggi ini biasanya memberikan tingkat pengembalian investasi yang tinggi juga. Demikian juga sebaliknya, Beta yang rendah menunjukkan tingkat risiko yang rendah pada suatu saham, namun hal ini membawa dampak pada kemungkinan rendahnya tingkat pengembalian investasi. Untuk para investor di pasar modal, Beta ini juga bisa menjadi salah satu alat ukur sebelum menentukan 
investasi yang akan dilakukan. Bila ingin mendapatkan keuntungan yang besar (tapi dengan kemungkinan rugi yang besar juga) maka bisa melakukan investasi pada saham dengan Beta yang tinggi. Tapi bila ingin melakukan investasi yang bersifat lebih aman, maka taruhlah pada saham dengan Beta yang rendah.

Namun penggunaan Beta dalam analisa investasi juga memiliki beberapa kelemahan. ertama, Beta dihitung berdasarkan data historis dimana data historis tidak selalu menjadi alat ukur yang akurat untuk masa depan. Kedua, Beta tidak melihat kepada perubahan perubahan yang sedang terjadi pada waktu tersebut (misalnya kebijakan pemerintah yang baru) yang mungkin mempengaruhi harga saham. Karena itu melihat pada kelemahan - kelemahan tersebut, sangat dianjurkan bagi Investor untuk mempergunakan Analisa Beta ini di dalam pengambilan keputusan investasi yang bersifat jangka pendek saja dimana perubahan - perubahan harga akan sangat berpengaruh. Jadi bagi investor yang bermaksud membeli dan menjual saham dalam jangka pendek, analisa Beta dapat menjadi salah satu analisa risiko yang baik. Untuk investasi yang bersifat jangka panjang, investor harus tetap memperhatikan fundamental dari suatu perusahaan yang akan memberikan gambaran yang lebih baik terhadap risiko jangka panjang dari suatu saham.

Laporan Keuangan bisa memberikan gambaran yang jelas untuk informasi mengenai faktor fundamental yang mempengaruhi Beta, salah satunya adalah Liquiditas dan Finansial
Laverage. Tandelilin (1997) melakukan pengujian terhadap pengaruh variabel fundamental dan faktor ekonomi makro terhadap beta. Hasil penelitian Tandelilin (1997) menunjukkan bahwa variabel makro ekonomi: produk domestik bruto, tingkat inflasi dan suku bunga tidak berpengaruh terhadap beta saham perusahaan non-keuangan selama periode 1990-1994. Sedangkan variabel fundamental secara bersama-sama mempunyai pengaruh yang signifikan positif. Penghitungan beta pada pasar modal yang sedang berkembang menghadapi kendala perdagangan yang tipis. Pasar yang tipis terjadi karena perdagangan yang jarang terjadi, banyak saham tidur, sehingga mengakibatkan beta menjadi bias. Oleh karena itu, perlu adanya penyesuaian terhadap penghitungan beta ( koreksi beta ).

Dari uraian di atas, maka tujuan utama dalam penelitian ini adalah 1) untuk melihat pengaruh Likuiditas terhadap Beta pada perusahaan setelah mengalami akuisisi, 2) untuk melihat pengaruh Financial Laverage terhadap Beta pada perusahaan setelah mengalami akuisisi

\section{LANDASAN TORITIS DAN HIPOTESIS \\ Pengertian Akuisisi}

Peraturan Pemerintah RI No 27 tahun 1998 tentang Penggabungan, Peleburan dan Pengambilalihan Perseroan Terbatas mendefinisikan akuisisi merupakan perbuatan hukum yang dilakukan oleh badan hukum yang perseorangan untuk mengambil alih baik seluruh atau sebagian besar saham perseroan yang dapat mengakibatkan beralihnya pengendalian terhadap 
perseroan tersebut. Pernyataan Standar Akutansi Keuangan No 22 mendefinisikan akuisisi dari persepektif akutansi adalah suatu penggabungan usaha dimana salah satu perusahaan yaitu pengakuisisi memperoleh kendali atas aktiva netto dan operasional perusahaan yang diakuisisi, dengan memberikan aktiva tertentu mengakui suatu kewajiban atau mengeluarkan saham.

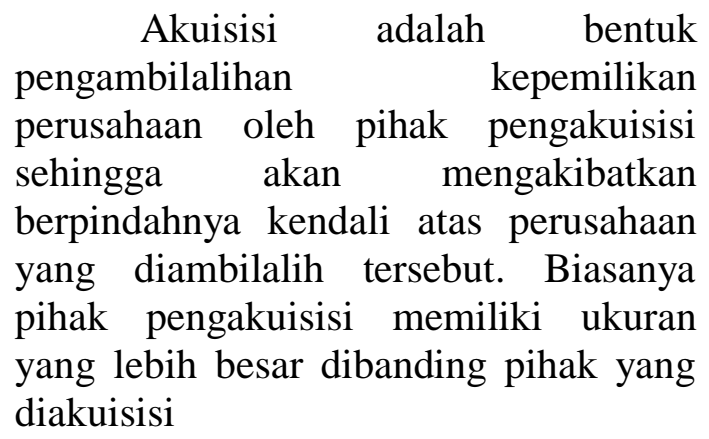

\section{Pengertian Saham}

Saham sebagai salah satu alternatif media investasi memiliki potensi tingkat keuntungan dan kerugian yang lebih besar dibandingkan media investasi lainnya dalam jangka pnjang. Saham adalah surat berharga yang merupakan tanda kepemilikan seseorang atau badan terhadap suatu perusahaan. Pengertian saham ini artinya adalah surat berharga yang dikeluarkan oleh sebuah perusahaan yang berbentuk Perseroan Terbatas ( PT ) atau yang biasa disebut emiten. Saham menyatakan bahwa pemilik saham tersebut adalah juga pemilik sebagian dari perusahaan tersebut. Dengan demikian seorang investor membeli saham, maka iapun menjadi pemilik atau pemegang saham perusahaan.

\section{Pengertian Resiko}

Resiko adalah kemungkinan perbedaan anatara return aktual yang diterima dengan return yang diharapkan. Semakin besar kemungkinan perbedaannya semakin besar resiko investasi tsb.Resiko dapat dibagi dua yaitu resiko tidak sistematis dan resiko sistematis (Elton dan Gruber 1995, Jones 1999, Hartono 2000). Resiko tidak sistematis merupakan resiko yang dapat dihilangkan dengan melakukan diversifikasi. Sedangkan resiko sistematis merupakan resiko yang melekat dan tidak dapat dihilangkan dengan melakukan diversifikasi. Resiko sistematis digambarkan oleh beta.

Beta merupakan pengukur risiko sistematis dari suatu saham atau portofolio relatif terhadap risiko pasar. Beta juga berfungsi sebagai pengukur volatilitas return saham, atau portofolio terhadap return pasar. Volatilitas merupakan fluktuasi return suatu saham atau portofolio dalam suatu periode tertentu, jika secara statistik fluktuasi tersebut mengikuti fluktuasi dari return-return pasar, maka dikatakan beta dari sekuritas tersebut bernilai satu. Penilaian terhadap Beta sendiri dapat dikategorikan ke dalam tiga kondisi yaitu:

1. Apabila Beta $=1$, berarti tingkat keuntungan saham i berubah secara proporsional dengan tingkat keuntungan pasar. Ini menandakan bahwa risiko sistematis saham i sama dengan risiko sistematis pasar.

2. Apabila Beta $>1$, berarti tingkat keuntungan saham i meningkat lebih besar dibandingkan dengan tingkat keuntungan keseluruhan saham di pasar. Ini menandakan bahwa risiko sistematis saham i lebih besar dibandingkan dengan risiko sistematis pasar, saham jenis ini sering juga disebut sebagai 
saham agresif.

3. Apabila Beta $<1$, berarti tingkat keuntungan saham i meningkat lebih kecil dibandingkan dengan tingkat keuntungan keseluruhan saham di pasar. Ini menandakan bahwa risiko sistematis saham i lebih kecil dibandingkan dengan risiko sistematis pasar, saham jenis ini sering juga disebut sebagai saham defensif.

Pengukuran beta suatu saham dapat dilakukan dengan menggunakan Single Index Model. Model ini berasumsi bahwa return saham berkorelasi dengan perubahan return pasar, dan untuk mengukur korelasi tersebut bisa dilakukan dengan menghubungkan return saham individual (ROt) dengan return indeks pasar (Rmt). Tingkat return saham ini dihitung dengan rumus berikut:

$\mathbf{R}_{\mathrm{it}}=\left(\mathbf{P}_{\mathrm{t}}-\mathbf{P}_{\mathrm{ti}}-\mathbf{1}\right) / \mathbf{P}_{\mathrm{t}}-\mathbf{1}$

\section{Likuiditas}

Fred Weston dikutip dari Kasmir (2008:129) menyebutkan bahwa rasio likuiditas (liquidity ratio) merupakan rasio yang menggambarkan kemampuan perusahaan dalam memenuhi kewajiban (utang) jangka pendek.Digunakan untuk menggambarkan seberapa likuidnya suatu perusahaan serta kemampuan perusahaan untuk menyelesaikan kewajiban jangka pendek dengan menggunakan aktiva lancar. Dengan kata lain, rasio ini digunakan untuk mengukur kemampuan perusahaan untuk membayar kewajiban yang segera jatuh tempo.

\section{Financial Laverage}

Financial leverage menurut Martono dan Harjito (2008:301), mengemukakan bahwa : " Financial Leverage merupakan penggunaan dana dengan beban tetap dengan harapan atas penggunaan dana tersebut akan memperbesar pendapatan per lembar saham (earning per share, EPS)".

Masalah financial leverage baru timbul setelah perusahaan menggunakan dana dengan beban tetap, seperti halnya masalah operating leverage baru timbul setelah perusahaan dalam operasinya mempunyai biaya tetap. Perusahaan yang menggunakan dana dengan beban tetap dikatakan menghasilkan leverage yang menguntungkan (favorable financial leverage) atau efek yang positif kalau pendapatan yang diterima dari penggunaan dana tersebut lebih besar daripada beban tetap dari penggunaan dana itu.

Kalau perusahaan dalam menggunakan dana dengan beban tetap itu menghasilkan efek yang menguntungkan dana bagi pemegang saham biasa (pemilik modal sendiri) yaitu dalam bentuknya memperbesar EPS-nya, dikatakan perusahaan itu menjalankan "trading on the equity".

Antonius Sinaga dalam Djayani Nurdin (1999) menyatakan bahwa risiko investasi pada saham dipengaruhi oleh faktor-faktor yang bersifat makro dan faktor-faktor yang bersifat mikro,meliputi : pertumbuhan ekonomi, tingkat bunga, nilai tukar valuta asing, tingkat inflasi, struktur modal, struktur aktiva, tingkat likuiditas, ukuran perusahaan, kebijakan pemerintah dibidang ekonomi. Hasil yang diperoleh menunjukkan bahwa variabel pertumbuhan ekonomi, tingkat inflasi, nilai tukar valuta asing, kebijakan pemerintah, ukuran perusahaan, struktur modal, struktur aktiva, dan tingkat likuiditas mempunyai pengaruh terhadap 
risiko investasi pada saham di Bursa Efek Jakarta, namun variabel tingkat bunga tidak mempunyai pengaruh terhadap risiko investasi saham.

Penelitian lain juga dilakukan oleh Pablo de Andres et al (2008) mengenai dampak pilihan pertumbuhan pada risiko sistematis studi kasus perusahaan Eropa. Variabel independen yang digunakan adalah opsi pertumbuhan pasar, dan financial leverage. Hasil penelitian ini menunjukkan bahwa variabel financial leverage berpengaruh positif dan signifikan terhadap risiko sistematis di semua industri. Sedangkan variabel opsi pertumbuhan pasar berpengaruh positif terhadap risiko sistematis dalam empat dari enam industri dan berpengaruh negatif dalam dua kelas-kelas risiko yang lain.

Berbeda dengan Nova (2013), dia menyimpulkan bahwa Beta dipengaruhi oleh Variabel Keuangan, yang mana Laverage, Dividend payout ratio dan Asset Growth tidak berpengaruh pada Beta saham, sedangkan Likuiditas memiliki pengaruh yang negatif, hanya Profitabilitas yang memiliki pengaruh yang positif terhadap Beta saham.

Dari uraian di atas maka dapat dirumuskan hipotesis sebagai berikut :

H1 : Likuiditas berpengaruh signifikan terhadap Beta pada perusahan yang terdaftar di Bursa Efek Indonesia setelah Akuisisi

$\mathrm{H} 2$ : Financial Laverage berpengaruh signifikan terhadap Beta pada perusahan yang terdaftar di Bursa Efek Indonesia setelah Akuisisi

\section{METODOLOGI PENELITIAN}

Penelitian ini merupakan jenis Deskriptif Kuantitatif. Penelitian ini menggunakan jenis data sekunder yaitu data yang diperoleh dari pihak lain dalam bentuk sudah jadi berupa publikasi. Data tersebut berupa data harga saham harian perusahaan yang melakukan akuisisi dan indeks harga saham gabungan (IHSG) harian.Adapun populasi dalam penelitian ini adalah semua perusahaan yang mengakuisisi dalam rentang tahun 2013-2017. Adapun jumlah populasi yang didapat adalah sebanyak 215 observasi.

Sampel diambil dengan metode Purposive Sampling, dan adapun sampel yang memenuhi kriteria adalah sebanyak 6 perusahaan dengan 15 tanggal pengumuman Akuisisi.

Metode koreksi beta dengan menggunakan metode Fowler dan Rorke (1983) 1 lead dan 1 lag adalah sebagai berikut:

0 Rmt $+\beta_{\mathrm{i}}{ }^{+1} \mathrm{Rmt}+1+\varepsilon_{\mathrm{it}}$

Metode koreksi beta dengan menggunakan metode Fowler dan Rorke (1983) 1 lead dan 1 lag adalah sebagai berikut:

0 Rmt $+\beta_{\mathrm{i}}^{+1} \mathrm{Rmt}_{+1}+\varepsilon_{\mathrm{it}}$

$$
\text { Rit }=\alpha_{i}+\beta_{\mathrm{i}}^{-1} \mathrm{Rmt}^{-1}+\beta_{\mathrm{i}}
$$

Untuk memperoleh bobot dalam penghitungan beta koreksi menggunakan rumus sebagai berikut:

$$
\begin{aligned}
& \mathrm{Rmt}=\alpha_{\mathrm{i}}+\rho_{1} \mathrm{Rmt}_{-1}+\varepsilon_{\mathrm{t}} \\
& \mathrm{W}_{\mathrm{i}}=\frac{1+\rho_{1}}{1+2 \cdot \rho_{1}}
\end{aligned}
$$

Bobot $\left(\mathrm{W}_{\mathrm{i}}\right)$ yang diperoleh dari persamaan terlebih dulu kemudian digunakan untuk menghitung beta koreksi sebagai berikut:

$$
\beta \mathrm{i}=\mathrm{Wi} \cdot \beta \mathrm{i}^{-1}+\beta \mathrm{i}^{0}+\mathrm{Wi} \cdot \beta_{\mathrm{i}}^{+1}
$$

Pengujian hipotesis menggunakan regresi berganda sebagai berikut:

$$
\mathrm{Y}=\mathrm{a}+\mathrm{b}_{1} \mathrm{X}_{1}+\mathrm{b}_{2} \mathrm{X}_{2}+\varepsilon
$$

Dimana : 


$$
\begin{array}{ll}
\mathrm{Y} & =\text { beta saham } \\
\mathrm{A} & =\text { intercept } \\
\varepsilon & =\text { error term } \\
\mathrm{b}_{1}-\mathrm{b}_{2} & =\text { koefisien regresi } \\
\mathrm{X}_{1} & =\text { liquidity } \\
\mathrm{X}_{2} & =\text { financial leverage }
\end{array}
$$

Berikut ini disajikan penghitungan variabel independen:

\section{Liquidity}

Liquidity yang dipakai dalam penelitian ini adalah current ratio yaitu aktiva lancar dibagi dengan hutang lancer.

$$
\text { liquidity }=\frac{\text { totalaktiva lancar }}{\text { totalhu } \tan \text { g lancar }}
$$

Dari rumus liquidity pertahun tersebut kemudian dihitung rata-rata liquidity (average liquidity) sebagai berikut :

Average liquidity $=\frac{\sum_{t=1}^{T} \text { liquidity }_{t}}{T}$

\section{Financial Leverage}

Financial leverage merupakan rasio untuk mengukur sejauh mana aktiva perusahaan dibiayai dengan hutang. Penghitungannya adalah sebagai berikut :

$$
\text { financialleverage }=\frac{\text { total } h u \tan g}{\text { total aktiva }}
$$

Dari rumus financial leverage pertahun tersebut kemudian dihitung rata-rata financial leverage (average leverage) sebagai berikut :

Average leverage $=\frac{\sum_{t=1}^{T} \text { leverage }_{t}}{T}$

\section{HASIL PENELITIAN} Hasil Deskriptif Statistik Uji Normalitas.

Data sudah diolah Dari hasil pengujian, terlihat bahwa besarnya nilai Kolmogorov-Smirnov untuk masing-masing variabel adalah 0.759 , nilai signifikan besar dari nilai alpha (sig $<$ alpha), hal ini berarti pengujian normalitas model regresi menunjukkan bahwa semua variabel yang terdapat pada penelitian ini berdistribusi normal.Maka variabel dapat dilanjutkan ke penelitian selanjutnya.

\section{Pengujian Hipotesis \\ Uji t ( Uji Parsial )}

Variabel Likuiditas(X1) sebagai variabel independen tidak memiliki pengaruh signifikan terhadap variabel Beta ( Y ) baik setelah dan sebelum Koreksi. Sebelum koreksi dari nilai signifikan Likuiditas yang lebih besar dari 5\% $(0.415>0,05)$ dengan $t$ hitung lebih kecil dari t tabel $(0.824<2.160)$. Dan setelah koreksi nilai signifikan Likuiditas yang lebih besar dari 5\% $(0.272>0,05)$ dengan $\mathrm{t}$ hitung lebih kecil dari $\mathrm{t}$ tabel $(1.148<2.160)$. Hasil pengujian model regresi dapat disimpulkan bahwa variabel likuiditas tidak berpengaruh terhadap Beta sebelum dan sesudah koreksi. Jadi hipotesis pertama ditolak, Likuiditas tidak berpengaruh signifikan terhadap Beta.

Begitu juga dengan variabel Financial Laverage ( X2) sebagai variabel independen tidak memiliki pengaruh signifikan terhadap variabel Beta ( Y ) . Hal ini dilihat dari nilai signifikan Financial laverage sebelum koreksi yang lebih besar dari 5\% $(0.793>0,05)$ dengan $t$ hitung lebih kecil dari t tabel $(0.268<2.160)$. dan setelah koreksi 
nilai signifikan Financial laverage yang lebih besar dari 5\% $(0.923>0,05)$ dengan $\mathrm{t}$ hitung lebih kecil dari t tabel $(0.099<2.160)$. Hasil pengujian model regresi di atas dapat disimpulkan bahwa variabel Financial Laverage tidak berpengaruh signifikan terhadap Beta sebelum koreksi. Jadi hipotesis kedua juga ditolak, Financial Laverage tidak berpengaruh signifikan terhadap Beta.

\section{Uji $\mathbf{R}^{\mathbf{2}}$ ( Uji determinasi )}

Dilihat dari kedua metode bahwa pengaruh kedua variabel bebas (Likuiditasdan Financial Laverage) atau independen terhadap variabel dependen (Beta) yang dinyatakan dengan nilai Adjusted $R 2$, yaitu sebesar 0,053 atau $5,3 \%$ terhadap beta sebelum koreksi dan 0.110 atau $11 \%$ pada beta setelah koreksi. Hal ini berarti hanya $5.3 \%$ dan $11 \%$ variabel Beta yang dapat dijelaskan oleh variabel Likuiditas dan Financial Laverage. Sedangkan sisanya sebesar $94.7 \%$ dan $89 \%$ dijelaskan oleh sebab-sebab lain di luar variabel yang merupakan kontribusi variabel bebas lain di luar kedua variabel independen tersebut yang tidak diteliti dalam penelitian ini.

\section{Uji F}

Berdasarkan perhitungan dengan F-test diperoleh nilai F-hitung sebesar 0.338 dan0.744 dengan nilai signifikansi (sig) sebesar 0.720 dan 0.496 . Oleh karena nilai signifikansi $0,496>0,05$, dan nilai hitung $0.744<3.88$ maka terdapat pengaruh yang tidak signifikan antara variabel Likuiditas dan Financial Laverage terhadap Beta. Artinya kedua variabel ini tidak simultan penjelas yang signifikan terhadap Beta

\section{PEMBAHASAN}

\section{Pengaruh Liquiditas terhadap Beta}

Hasil penelitian ini menunjukan bahwa Liquiditas tidak berpengaruh signifikan terhadap Beta saham baik sebelum ataupun setelah di koreksi dapat dilihat dari nilai signifikan Likuiditas yang lebih besar dari 5\% yaitu 0.415 dan 0.272 dengan t hitung lebih kecil dari t tabel (1.148 dan 0.842 lebih kecil daripada 2.160).Sehingga Hipotesis yang pertama ditolak.

Hal ini menujukan bahwa Likuiditas tidak memiliki sinyal bagi investor dalan mengestimasi risiko terutama resiko sistematik yang akan ditanggung pada perusahaan.

Hasil ini sesuai dengan penelitian Jugianto ( 2005 ) yang memperoleh kesimpulan bahwa likuiditas yang diukur menggunakan current Rasio mempunyai pengaruh negatif signifikan terhadap risiko sitematik. Begitu juga dengan penlitian Firlika ( 2013 ) bahwa Financial Laverage dan Likuiditas tidak berpengaruh signifikan terhadap resiko sistematik saham.

\section{Pengaruh Financial Laverage terhadap Beta}

Hasil penelitian ini menunjukan bahwa Financial Laverage tidak memiliki pengaruh terhadap beta saham sebelum dan sesudah koreksi, ini dibuktikan dengan nilai signifikan Financial laverage yang lebih besar dari 5\% dengan t hitung lebih kecil dari $\mathrm{t}$ tabel. Penelitian ini menunjukan bahwa besarnya jumlah hutang yang dimiliki oleh suatu perusahaan tidak berarti semakin besar resiko sitematik ( Beta ) yang muncul dari perusahaan tersebut.

Menurut Howton dalm Sharli dan Oktorina ( 2005 ) perusahaan, laverage 
mempunyai peluang investasi yang tidak menguntungkan serta arus kas bebas tinggi. Dengan membedakan perusahaan yang pembayaran devidennya tinggi dengan yang rendah, dikatakan bahwa perusahaan yang pembayaran devidennya rendah mempengaruhi harga saham secara positif pada pengumuman penawaran hutang. Kebijakan hutang dinyatakan dalam rasio laverage.

Mengenai Laverage ini pernah di ungkapkan oleh Nova ( 2013 ) Melalui tesisnya bahwa Financial Laverage tidak berpengaruh kepada beta saham.

\section{KESIMPULAN， KETERBATASAN DAN SARAN \\ Kesimpulan}

Penelitian ini bertujuan untuk melihat pengaruh Likuiditas dan Financial Laverage terhadap Beta pada perusahaan yang mengalami Akuisisi yang terdaftar di Bursa Efek Indonesia periode 2013-2017. Berdasarkan hasil penelitian tersebut disimpulkan bahwa :

1. Likuiditas tidak berpengaruh signifikan terhadap Beta Saham setelah Akuisisi.

2. Financial Leverage juga tidak memiliki pengaruh yang signifikan terhadap Beta saham setelah Akuisisi.

\section{Keterbatasan dan Saran}

Peneliti menyadari penelitian yang peneliti lakukan masih jauh dari kesempurnaan dan masih memiliki keterbatasan-keterbatasan yang mungkin yang akan mempengaruhi hasil penelitian. Oleh karena itu keterbatasan ini diharapkan lebih dapat diperhatikan oleh peneliti-peneliti yang akan datang, dimana keterbatasan-keterbatasan yang peneliti rasakan selama penelitian antara lain :
1. Data yang ada belum mewakili semua sektor perusahaan, karena didalam sampel yang memenuhi persyaratan dalam penelitian ini belum mewakili semua sector perindustrian..

2. Variabel yang digunakan sangat terbatas hanya menggunakan variable Likuiditas dan Financial Laverage, karena setelah didapatkan dari hasil penelitian, masih ada variabel yang lain yang mempengaruhi Beta saham di BEI yang tidak diteliti dalam penelitian ini.

\section{Saran}

Berdasarkan hasil penelitian ini, penulis mencoba memberikan saran bagi perusahaan dalam menentukan risiko sistematis (beta) saham variabel-variabel Likuiditas dan Financial Laverage yang digunakan dalam penelitian ini belum bisa menjadi acuan dalam penentuan berapa besar risiko sistematis (beta) saham perusahaan menjadi objek penelitian. Untuk menekan risiko sistematis, perusahaan disarankan tidak hanya meperhatikan faktor internal perusahaan, tetapi juga memperhatikan faktor eksternal seperti tren harga saham, kurs, suku bunga, inflasi, kondisi politik dan kondisi pasar.

Sedangkan untuk investor Risiko sistematis yang tidak dapat didiversifikasi menjadi pertimbangan khusus bagi para investor dalam menentukan investasinya. Indikator dalam penelitian ini yaitu Likuiditas dan Financial Laverage tidak cukup menjadi acuan investor dalam menentukan risiko sistematis (beta) saham. Disarankan untuk investor juga memperhatikan faktor-faktor lain yang dapat mempengaruhi risiko sistematis 
saham. Selain itu dalam investasi hendaknya investor mempertimbangkan pembentukan portofolio yang optimal yang mengkombinasikan saham-saham di berbagai industri yang ada untuk mengurangi risiko industri.

\section{DAFTAR PUSTAKA}

Danil, A., \& Yusra, I. (2019). Pengaruh kausal antara ukuran perusahaan, nilai buku dan likuiditas saham di Bursa Efek Indonesia. INA-Rxiv.

Fajri, I., \& Dewi, A. S. (2019). Analisis Likuiditas, Profitabilitas, dan Return Saham pada Perusahaan Manufaktur di Indonesia. INA-Rxiv.

Ghozali Imam, 2012, Aplikasi Analisis Multivariate Orogram IBM SPSS 20, Cetakan ke VI, Badan Penerbit Universitas Diponegoro.

Hadya, R. (2013a). Pengaruh Harga dan Risiko Saham Terhadap Likuiditas Saham Pada Perusahaan-Perusahaan Yang Terdaftar Di Bursa Efek Indonesia. Jurnal KBP, 1(2), 208-231.

Hadya, R. (2013b). Pengaruh Harga dan Risiko Saham terhadap Likuiditas Saham Pada Perusahaan-Perusahaan Yang Terdaftar Di Bursa Efek Indonesia. Jurnal KBP, 1(2), 208-231. Retrieved from https://akbpstie.ac.id/cmsz/medias/f ile/9. rizka hadya.pdf

Hadya, R. (2014a). Analisis likuiditas, solvabilitas, nilai pasar dan return saham: studi empiris pada perusahaan sektor perbankan yang terdaftar di Bursa Efek Indonesia.
Jurnal Riset Manajemen Dan Akuntansi, 3(1), 107-118.

Hanafi, D., \& Yusra, I. (2019). Tangibility, liquidity, growth opportunity, dan leverage: studi pada perusahaan terdaftar di Bursa Efek Indonesia. INA-Rxiv, (2001).

Maulana, I., \& Martha, L. (2017). Analisis Likuiditas dan Struktur Keuangan terhadap Kinerja Keuangan pada Perusahaan Telekomunikasi yang Terdaftar di Bursa Efek Indonesia. INA-Rxiv.

Mulfita, A., \& Yusra, I. (2019). Analisis regresi data panel terhadap likuiditas saham di Indonesia. INA-Rxiv.

Putra, I., \& Yusra, I. (2019). Analisis likuiditas saham menggunakan regresi data panel. INA-Rxiv.

Riyanto, Bambang, 2008. Dasar-dasar Pembelajaran Perusahaan, BPFE, Yogyakarta.

Yusra, I. (2014). Analisis Return dan Likuiditas Saham Sebelum dan Sesudah Pengumuman Right Issue di Bursa Efek Indonesia. Jurnal Riset Manajemen Dan Akuntansi, 1(2), 150-163. 